\title{
Help for Unemployed Borrowers: Lessons from the Pennsylvania Homeowners' Emergency Mortgage Assistance Program
}

\author{
James Orr, John Sporn, Joseph Tracy, and Junfeng Huang
}

In an environment of high foreclosure rates and distressed housing markets, federal policies are focusing on loan modifications to help delinquent homeowners pay their mortgages. While it is too soon to assess the effectiveness of these modifications, policymakers considering future refinements may gain insight from a more established, state-level enterprise that takes an alternative approach to mortgage relief. The Pennsylvania Homeowners' Emergency Mortgage Assistance Program provides temporary income support to homeowners unable to pay their mortgage during a spell of unemployment. The program has helped most participants retain their homes while paying off their loansat a potentially lower cost than that of other relief initiatives.

C ontinuing high levels of mortgage foreclosures and ongoing weakness in the housing market have spurred public policy interest in helping homeowners meet their mortgage payments. At the federal level, policies have centered on providing incentives for the modification of delinquent mortgages. Prominent among the government's efforts is the Home Affordable Modification Program (HAMP), announced in March 2009. ${ }^{1}$ HAMP encourages lenders and servicers to modify the terms of the mortgage contract-in particular, the interest rate and maturity of the loan-in a way that increases affordability for homeowners. The rationale behind HAMP and similar interventions is that while home foreclosures impose costs on borrowers and lenders/servicers, they also undermine the value of other properties in neighborhoods where the foreclosed residences are located.

A more recent federal effort to assist delinquent borrowers is the Emergency Homeowners' Loan Program (EHLP), introduced by the Department of Housing and Urban Development (HUD) in August 2010. ${ }^{2}$ This program provides interest-free loans to borrowers to pay arrearages plus a portion of their monthly mortgage when the borrowers experience a significant loss of income. Under the terms of the program, income loss can result not only from unemployment but also from underemployment or a medical emergency, and assistance is available for up to two

\footnotetext{
${ }^{1}$ See http://www.makinghomeaffordable.gov/modification_eligibility.html.

2 The program was established by the Dodd-Frank Wall Street Reform and Consumer Protection Act. HUD is working to implement EHLP and hopes to begin accepting homeowner applications soon (see http://portal.hud.gov/hudportal/HUD?src=/press/testimonies/2011/2011-03-02b).
} 
years. ${ }^{3}$ Loss of income is now a primary cause of mortgage defaults; for borrowers who had an affordable mortgage prior to the loss, income assistance may be preferable to mortgage modification as a way to minimize default risk.

While it is too soon to evaluate fully the effectiveness of HAMP and EHLP, some comparisons can be made with a more established, state-level assistance program. EHLP in particular shares a number of features with the Homeowners' Emergency Mortgage Assistance Program (HEMAP), a Pennsylvania initiative that provides temporary financial assistance to borrowers who become delinquent on their mortgages because of unemployment or other financial hardship beyond their control. HEMAP has operated in Pennsylvania for more than twenty-five years, so a solid track record of its performance is available to examine.

In this edition of Current Issues, we review the structure and performance of HEMAP and suggest some features of the state program that could help inform federal efforts to address the problem of delinquent unemployed borrowers. A measure of HEMAP's success is that the majority of participants have remained in their homes and ultimately paid off their loans. The effectiveness of this form of assistance, however, is likely linked to the program's careful screening process, which limits participation to applicants with a good mortgage payment history and a high likelihood of resuming their full mortgage payments within two years. For these applicants, the program appears to provide a useful alternative to loan modification.

Our analysis also offers a comparison of HEMAP and HAMP. Using a hypothetical example of a borrower who becomes delinquent in making mortgage payments during an interval of unemployment, we show that the budgetary cost of making a HEMAP loan can be substantially lower than the cost of a permanent HAMP modification. We also discuss key differences between HEMAP loans and loans provided through HUD's EHLP initiative.

In the article's final section, we suggest a number of refinements to HEMAP that policymakers might wish to consider if a similar program were to be implemented elsewhere. These refinements include improving the targeting and timing of program benefits as well as tightening the loan approval criteria. Such steps should help lower the risk of delinquencies and defaults and also reduce the size of the loans needed by borrowers. The extension of loans to negative equity borrowers - homeowners who owe more on their mortgages than their homes are worth-

\footnotetext{
${ }^{3}$ A similarly tailored program of temporary assistance to delinquent borrowers who face a loss of income is operated by the Government of Ireland. The Mortgage Interest Supplement Program provides loans to eligible borrowers to pay the interest portion of their mortgage while they seek reemployment (see http:// www.citizensinformation.ie/en/social_welfare/social_welfare_payments/ supplementary_welfare_schemes/mortgage_interest_supplement.html).
}

has not been a feature of HEMAP. If similar programs were put into effect in states where steep declines in home values have left many homeowners in a negative equity position, administrators would likely have to make loans to these borrowers contingent upon mortgage lenders' willingness to reduce the principal on the loan.

\section{Origins of HEMAP}

The Pennsylvania Homeowners' Emergency Mortgage Assistance Program was established by the Pennsylvania Foreclosure Prevention Act 91 of 1983 and signed into law on December 23, 1983. One of the program's stated objectives was to prevent distressed home sales, which were believed to be very damaging to many communities in the state. HEMAP was designed to help homeowners who, through no fault of their own, are temporarily unable to make full mortgage payments and thus are in danger of losing their home to foreclosure. The cause of the financial hardship is not limited to unemployment, but includes other factors such as illness, divorce, and labor strikes. The program is administered by the Pennsylvania Housing Finance Agency (PHFA) and funded by a combination of annual state appropriations and the repayment of principal and interest on existing HEMAP loans. ${ }^{4}$

At the time HEMAP was established, the labor market in Pennsylvania had been deteriorating for several years. Statewide, total employment had been declining since the start of the decade and the unemployment rate by late 1983 had reached more than 13 percent, about two percentage points above the national rate (Chart 1). Within the state, unemployment rates were particularly high in Pittsburgh, at more than 16 percent, and Allentown, at more than 15 percent (Chart 2). Cyclical increases in unemployment rates were compounded at that time by the adverse effects of structural changes in several major industries in the Pennsylvania economy, including steel and transportation. The duration of state unemployment was also relatively high in 1983: roughly 4 percent of the labor force-about twice the comparable U.S. rate-had been unemployed more than twenty-six weeks. ${ }^{5}$ Since the mid-1980s, the unemployment rate in Pennsylvania has roughly matched that of the nation, though in the current downturn it has not risen as much.

The housing market in Pennsylvania had been weakening prior to the adoption of HEMAP. Nationally, nominal home price growth rates had slowed from an annual rate of approximately 15 percent to about 2 percent between 1980 and 1983, and a similar slowing was seen in metropolitan areas in Pennsylvania (Chart 3). Growth rates in the Philadelphia, Pittsburgh, and Allentown areas were quite volatile in this period, but they followed a broadly similar

\footnotetext{
${ }^{4}$ More details on HEMAP's operation are available at http://www.phfa.org/ consumers/homeowners/hemap.aspx.

${ }^{5}$ Calculations are from the Current Population Survey, 1983 outgoing rotation groups.
} 
Chart 1

\section{Unemployment Rate: Pennsylvania and the United States}

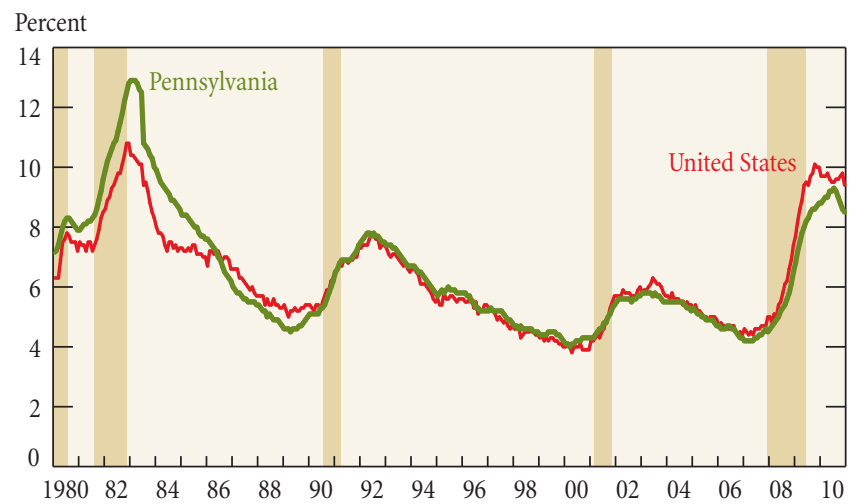

Source: Moody's Economy.com.

Note: The vertical bands indicate periods designated national recessions by the National Bureau of Economic Research.

\section{Chart 2 \\ Unemployment Rate: Pennsylvania Metro Areas and the United States}

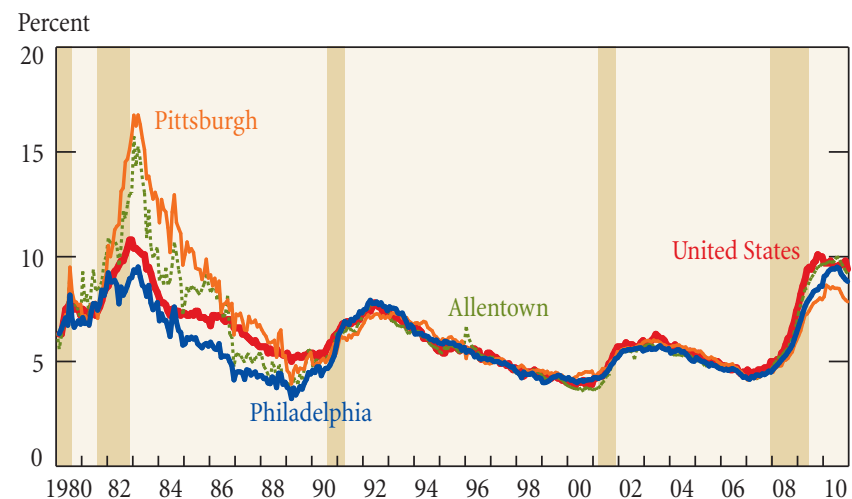

Source: Moody's Economy.com.

Note: The vertical bands indicate periods designated national recessions by the National Bureau of Economic Research.
Chart 3

\section{House Price Growth: Pennsylvania Metro Areas and the United States}

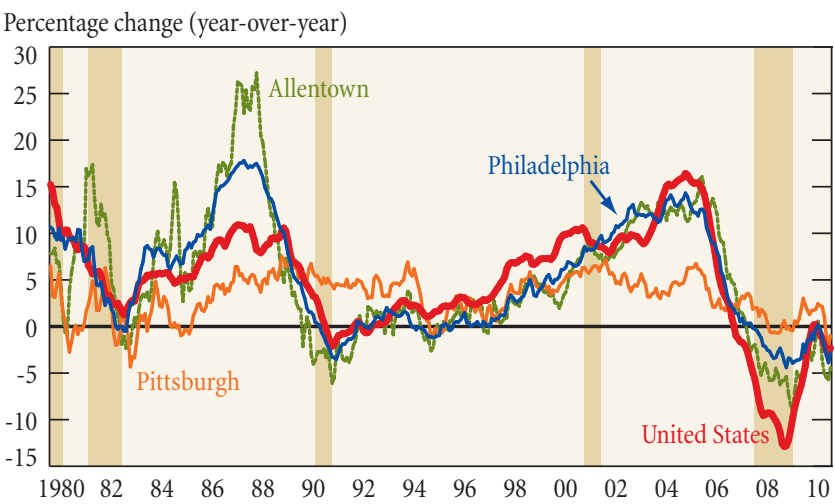

Source: CoreLogic Loan Performance data.

Note: The vertical bands indicate periods designated national recessions by the National Bureau of Economic Research.

Chart 4

Seriously Delinquent Mortgages: Pennsylvania and the United States

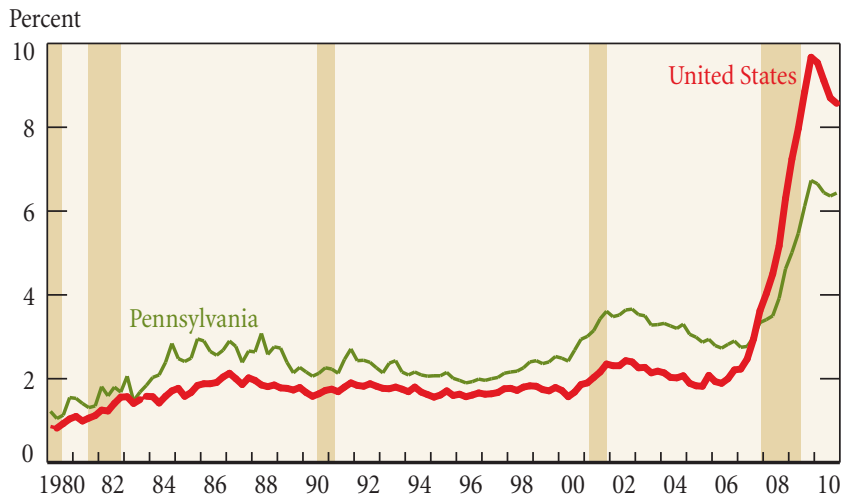

Source: Moody's Economy.com.

Note: The vertical bands indicate periods designated national recessions by the National Bureau of Economic Research. pattern of weakness before beginning to recover in $1984{ }^{6}$ The slowing in home price growth during this period contrasts with the outright declines in home prices since late 2007, both nationally and in several major housing markets in the state. Mortgage delinquencies and foreclosures also began to rise in late 1982 and into 1983. Statewide, the share of outstanding mortgages delinquent either ninety days or more or in foreclosure rose from about 1.0 percent to close to 2.0 percent between 1980 and 1983 (Chart 4).

\footnotetext{
${ }^{6}$ The index of home price growth rates is constructed from CoreLogic Loan Performance data and is based on repeat, nondistressed property sales.
}

\section{Operation of HEMAP}

An unemployed borrower entering the HEMAP loan process goes through several steps, and the program can begin to provide assistance roughly nine months after unemployment begins (see exhibit on page 4). Borrowers can initiate the application process for a HEMAP loan when they become sixty days delinquent on their mortgage. In general, the length of time between the income loss and the beginning of assistance depends on the length of time the unemployed borrower manages to keep paying the mortgage before becoming sixty days 


\section{Sample Timeline for the HEMAP Loan Process}

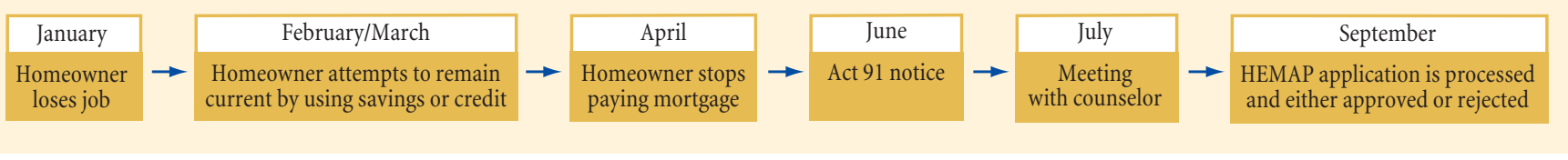

Note: HEMAP is the Pennsylvania Homeowners' Emergency Mortgage Assistance Program.

delinquent as well as the length of time it takes to determine eligibility after an application has been filed. ${ }^{7}$

\section{Determining Eligibility for a HEMAP Loan}

Lenders are required to notify borrowers ("Act 91 notice") of their eligibility to apply for a HEMAP loan when they become sixty days delinquent on a mortgage. After receiving notification, a borrower has thirty-three days to meet face to face with a consumer credit counseling agency, after which the agency has thirty days to forward an application to the PHFA. Applications are carefully screened for the borrower's mortgage payment history and reemployment prospects. Currently, HEMAP eligibility is based on property and borrower characteristics. The property must be a one- or two-family owner-occupied residence located in Pennsylvania. ${ }^{8}$ The property cannot be encumbered by more than two loans. The borrower must meet all of the following requirements:

- be suffering financial hardship due to circumstances beyond his or her control, including unemployment, illness, or divorce;

- have a reasonable prospect of resuming full mortgage payments within twenty-four months, or thirty-six months in periods of high unemployment;

- be a permanent resident of Pennsylvania;

- have a favorable mortgage credit history prior to the current financial hardship, meaning the homeowner should not have been delinquent for more than three months within the past five years unless that delinquency was due to circumstances deemed to be beyond the homeowner's control; and

- be no more than twenty-four months delinquent or require no more than $\$ 60,000$ to make the mortgage current.

A borrower's ability to meet the last three eligibility criteria can be determined readily through loan and payment documentation from the lender. However, verifying the first two criteria,

\footnotetext{
${ }^{7}$ The program provides eligible borrowers with a noncontinuing loan to make the mortgage current and a continuing loan to provide assistance with monthly mortgage payments.

${ }^{8}$ Borrowers with an FHA Title II mortgage for mobile or manufactured homes are ineligible.
}

associated with financial hardship and the potential to resume full mortgage payments, requires program administrators to obtain evidence from other sources and to apply their judgment. Workers who quit their jobs or who are fired for cause are ineligible for a HEMAP loan. With regard to other forms of financial hardship, the program administrators would likely have to gather other documentary evidence. Determining an unemployed worker's prospects for reemployment in the same geographic location is more difficult. Reemployment prospects in the same local labor market are important because HEMAP was designed in part as a way of keeping workers in their homes while they sought reemployment.

\section{HEMAP Administration}

Lenders and borrowers have responsibilities under the Pennsylvania Foreclosure Prevention Act, and meeting those responsibilities prevents the taking of any legal action to foreclose on the property. Recall that the lender is required to notify any eligible borrower when the mortgage is sixty days delinquent. The borrower is required to arrange for and attend a face-to-face meeting with a consumer credit counseling agency within thirty-three days of receipt of the notice, and the counseling agency helps the borrower prepare the HEMAP application. The lender cannot pursue legal action against the borrower's property during that thirty-three-day period and for an additional thirty days after the borrower's meeting with the counseling agency.

During the application process, the borrower is required to provide general financial information, including tax returns, outstanding credit balances and payments, an itemized listing of living expenses, and a verification of employment status. Upon certification that the property and borrower meet the guidelines for participation, a HEMAP loan is authorized, which brings the mortgage current by paying off arrearages, court costs, and attorney fees incurred by the lender. The loan proceeds go directly to the lender. For a continuing loan, the total monthly mortgage payments made to the lender/ servicer remain the same but the borrower's contribution to the mortgage payment is capped at 40 percent of his or her "net effective income." 9 If the borrower's net effective income changes over the loan period, then the monthly loan payments

${ }^{9}$ Net effective income is gross income, including any unemployment insurance benefits, minus federal, state, and local income taxes. 


\section{HEMAP Performance Measures}

Panel A: Application Outcomes, 1983-2009

\begin{tabular}{lcc} 
Status & $\begin{array}{c}\text { Number of } \\
\text { Applicants }\end{array}$ & $\begin{array}{c}\text { Percent of } \\
\text { Applicants }\end{array}$ \\
\hline Received & 183,040 & \\
Rejected & 138,300 & 75.6 \\
Inactive/no decision & 1,593 & 0.8 \\
Approved & 43,147 & 23.6
\end{tabular}

Panel B: Funding Provided, in Millions of Dollars

\begin{tabular}{lrrrr} 
& \multicolumn{4}{c}{ Fiscal Year } \\
\cline { 2 - 5 } Source & 2007 & 2008 & 2009 & 2010 \\
\hline Loan repayments & 15.4 & 11.4 & 9.1 & 8.3 \\
State appropriations & 10.0 & 11.0 & 11.0 & 11.0 \\
Other funding $^{\mathrm{a}}$ & 0.0 & 0.2 & 0.3 & 5.1
\end{tabular}

Source: Pennsylvania Housing Finance Agency.

Note: HEMAP is the Pennsylvania Homeowners' Emergency Mortgage Assistance Program.

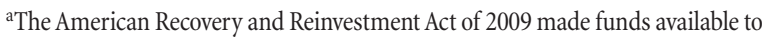
reimburse states for increased costs associated with certain types of assistance they provided to low-income families during the recession. In fiscal year 2010, Pennsylvania received \$5 million for costs associated with HEMAP.

are adjusted accordingly. Payments are made to the lender/ servicer on behalf of the borrower for a period of up to twenty-four months, with a cap of $\$ 60,000$ on total payments. This loan term can be extended to thirty-six months in periods of high unemployment rates (when the Pennsylvania rate is or exceeds 6.5 percent), and the borrower's contribution is lowered to 35 percent. ${ }^{10}$ The interest rate on HEMAP loans varies over time with market conditions; it is 5.25 percent for loans originated in 2010.

The structure of the loan makes the PHFA a lienholder on the property behind the first and possibly a second lienholder. The loan is nonrecourse; thus, if the property is ultimately sold in foreclosure, the state may see losses if the proceeds are insufficient to reimburse it for the full value of the loan. ${ }^{11}$ In a number of circumstances, a HEMAP loan can be terminated by the administrator, making the entire loan balance immediately due. One is when the borrower fails to make a mortgage payment on time for reasons unrelated to his or her financial condition. A second is when the borrower no longer occupies the residence. A third circumstance occurs when the mortgagor is able to

\footnotetext{
${ }^{10}$ This extension clause is an added source of flexibility in HEMAP, because it recognizes the potential for spells of unemployment to lengthen during periods of high unemployment.

11 The borrower may choose to continue to make the HEMAP loan payments, in which case the state will not send an adverse report to the credit rating agencies.
}

establish credit and the loan administrator determines that there is sufficient equity in the property for the mortgagor to refinance at reasonable rates and terms. Failure to repay the loan in these circumstances is counted against the borrower's credit standing.

\section{HEMAP Benefits and Costs}

Lending to an unemployed borrower is a risky propositionone that private lenders would decline to undertake. If a public program makes these loans with an eye to protecting taxpayer dollars, then the approval rate will likely be low. Since HEMAP's introduction in 1983, roughly 183,000 mortgagors have applied for a loan and 43,000, or about 23 percent, have been approved (Table 1). ${ }^{12}$ On average, 85 percent of denials are triggered by the applicant's circumstances, such as being fired from his or her job, quitting voluntarily, or lacking reasonable prospects of resuming full mortgage payments within twenty-four or thirty-six months based on income history. In 2009, for example, 14,000 borrowers applied for HEMAP loans and 3,250, or 23 percent, were approved. About 15 percent of the 2009 applicants were rejected for failing to provide the proper income and employment verification documents to the administrator. Pennsylvania offers rejected applicants free counseling regarding other options available to delinquent homeowners.

A key measure of success for HEMAP is the extent to which the program prevents unemployed borrowers from losing their homes. To date, around 80 percent of HEMAP loan recipients have retained ownership of their residences. Also important to the program's ongoing success is the extent to which HEMAP loans are repaid. ${ }^{13}$ Loan repayments are an important source of the program's continued funding, and the high loan repayment rate attests to the program administrators' ability to screen applicants on their reemployment prospects.

Funding for HEMAP at the outset was supplied entirely by the State of Pennsylvania. The state provided an initial appropriation of \$25 million in fiscal year 1984 to get the program off the ground. During fiscal years 1998-2004 - a period when the state unemployment rate roughly matched the national average and remained below 6.5 percent - the program received no additional state funding and relied solely on the proceeds from existing loans. ${ }^{14}$ In fiscal years 2005-09, total funding for the program ranged from $\$ 20$ million to $\$ 25$ million. State appropriations averaged \$10 million annually, and repayment of principal and interest accounted for the remainder of the funding. In fiscal year 2010, which ended on June 30, an additional \$5 million was made available to Pennsylvania by the federal government through the Temporary Assistance for Needy Families Program. The annual

\footnotetext{
12 Figures are based on data available through October 2009.

${ }^{13}$ All HEMAP participants had experienced a loss of income; however, we do not have data on their demographic and other characteristics and experiences to conduct a more complete evaluation of the program's effectiveness.

${ }^{14}$ See http://www.treasury.gov/initiatives/financial-stability/results/ MHA-Reports/Documents/Dec\%202010\%20MHA\%20Report\%20Final.pdf.
} 
cost of administering HEMAP is about $\$ 4.5$ million, or $\$ 320$ per application processed. On average, the monthly HEMAP contribution has been roughly $\$ 500$.

\section{Comparison of HEMAP and HAMP}

In March 2009, the Home Affordable Modification Program was announced with a goal of modifying 3 to 4 million mortgages. To date, 580,000 mortgages have received a permanent modification through the federal program. The predominant hardship resulting in a HAMP modification is a loss of income, accounting for 60 percent of modifications. ${ }^{15}$ Certain similarities between HAMP and Pennsylvania's assistance program suggest that a comparison of program designs could be worthwhile, and that the insight gained could prove beneficial to policymakers.

The objectives of HEMAP and HAMP are to enable the borrower to remain in his or her house during a spell of unemployment and to avoid a forced sale of the property. However, the programs take different approaches to addressing the problem of a temporary income shortfall. The HEMAP application process, like the HAMP process, begins when the borrower is in serious delinquency. ${ }^{16}$ HEMAP provides assistance in the form of a loan to the borrower during the period of unemployment. No active participation is required of the lender/servicer once it refers the borrower to HEMAP. Assistance ends when the borrower becomes reemployed, at which time he or she begins to repay the loan.

HAMP provides assistance by modifying the borrower's current mortgage. The borrower's monthly payment is reduced to produce a debt-to-income (DTI) ratio of $0.31 .{ }^{17}$ HAMP reaches this lower payment level by reducing the interest rate on the mortgage to a minimum of 2 percent, increasing the term of the mortgage to a maximum of forty years, and, if necessary, providing interest forbearance on some portion of the loan balance or providing principal forgiveness. ${ }^{18}$ These adjustments to the mortgage reduce the amount received by the lender/servicer and remain in effect for five years, independent of when the borrower may return to employment (or full employment). After meeting the qualification requirements, a borrower is first given a temporary

\footnotetext{
${ }^{15}$ See http://www.treasury.gov/initiatives/financial-stability/results/ MHA-Reports/Documents/Dec\%202010\%20MHA\%20Report\%20Final.pdf.

${ }^{16} \mathrm{~A}$ borrower may also qualify for a HAMP modification if he or she is current or less than sixty days delinquent on the mortgage, but faces imminent default.

17 The borrower's monthly debt is inclusive of taxes and insurance. The DTI ratio of 0.31 is similar to the HEMAP target of 40 percent given that HEMAP uses income net of taxes while HAMP does not.

${ }^{18}$ The principal reduction alternative (PRA) component of HAMP began in October 2010; through the PRA, principal reduction is considered before interest rate reductions and loan term extensions to reduce monthly payments for negative equity borrowers (see https://www.hmpadmin.com/portal/programs/ docs/hamp_servicer/sd1014.pdf).
}

Table 2

\section{A HAMP-HEMAP Comparison}

\begin{tabular}{|c|c|c|c|c|}
\hline & Origination & $\begin{array}{c}\text { Time of } \\
\text { Unemployment }\end{array}$ & HAMP & HEMAP \\
\hline House value & 220,000 & 210,000 & 210,000 & 210,000 \\
\hline Mortgage balance & 200,000 & 194,936 & 205,728 & 192,876 \\
\hline Monthly income & 4,608 & 2,673 & 2,673 & $2,327^{\mathrm{a}}$ \\
\hline Interest rate (percent) & 6.00 & 6.00 & 2.24 & 6.00 \\
\hline Taxes and insurance & 183 & 183 & 183 & 183 \\
\hline Principal and interest & 1,199 & 1,199 & 645 & 1,199 \\
\hline $\begin{array}{l}\text { Principal, interest, } \\
\text { taxes, and insurance }\end{array}$ & 1,382 & 1,382 & 828 & $930^{\mathrm{b}}$ \\
\hline DTI ratio & 0.30 & 0.52 & 0.31 & 0.40 \\
\hline HEMAP loan & & & & 14,856 \\
\hline $\begin{array}{l}\text { Program cost per } \\
\text { mortgage }\end{array}$ & & & 13,588 & 1,620 \\
\hline Annual interest subsidy & & & 6,697 & 0 \\
\hline
\end{tabular}

Source: Authors' calculations.

Notes: Figures are in dollars except where noted. HAMP is the Home Affordable Modification Program; HEMAP is the Pennsylvania Homeowners' Emergency Mortgage Assistance Program. The program cost assumes that the borrower does not redefault on the modified mortgage or the HEMAP loan; it does not include administrative costs.

aAfter-tax income assuming a 25 percent tax rate on earned income.

${ }^{\mathrm{b}}$ Amount paid by borrower excluding HEMAP subsidy.

modification and then must make three monthly payments on time to have the modification made permanent.

Because the mortgage must be modified, HAMP requires the involvement of the lender/servicer. The program provides a series of financial incentives to encourage participation. There is an upfront fee of $\$ 1,000$ paid to the lender/servicer for each permanent modification. There is also a series of "pay-for-performance" fees. In the first three years after a permanent modification, HAMP pays $\$ 1,000$ to the lender/servicer each year if the borrower remains current. The borrower accrues credits of $\$ 1,000$ a year for up to five years that can be used to reduce the mortgage balance if the loan remains current after the permanent modification.

We compare the two approaches by providing a detailed example (Table 2). We consider a household that purchases a $\$ 220,000$ home and takes out a $\$ 200,000$ mortgage to finance the purchase. The interest rate on the mortgage is 6 percent and the monthly payment, including property taxes and home insurance, is $\$ 1,382$. There are two earners in the household, with the principal earner bringing in 70 percent of the total income. The household's combined monthly pretax income is $\$ 4,608$. These figures imply that the DTI ratio on the mortgage is 0.30 . Given the earners' combined incomes, the household can afford the mortgage. 
Two years after the purchase of the house, the value has declined to $\$ 210,000$ and the principal earner becomes unemployed. The earner receives unemployment insurance benefits, but the household's monthly income is now reduced to $\$ 2,673 .{ }^{19}$ This raises the DTI ratio to 0.52 . Consequently, the household is unable to make its mortgage payments, and after sixty days of delinquency it applies for assistance. Nine months following the earner's job loss, either a HAMP modification is granted or a HEMAP loan is approved.

\section{Features of a HAMP Loan Modification}

Assume that the household applies for and is granted a HAMP modification. The interest rate on the new mortgage, which now includes a total of $\$ 10,792$ in arrearages, is reduced to 2.24 percent and the term is increased to forty years (see Table 2). The combination reduces the monthly principal and interest payment from $\$ 1,199$ to $\$ 645$, or $\$ 554$ less per month, and the total monthly payment inclusive of taxes and insurance falls to $\$ 828 .^{20}$ This lower monthly payment reduces the DTI ratio from 0.52 to 0.31 . The lower monthly payment under the HAMP modification stays in effect for up to five years. The lender/servicer sees a reduction in the amount of interest received over the five-year period, which is partially offset by its incentives to participate. The cost to the government includes these incentives to the lender/ servicer plus half the cost of the reduction of the DTI ratio from 0.38 to 0.31 . In this case, the latter cost is $\$ 188$ per month and the federal government pays half, or $\$ 94$, to the lender. If the household makes all of its monthly payments in a timely manner during these five years, the discounted cost to the government of the HAMP modification is about $\$ 13,600 .^{21}$

\section{Features of a HEMAP Loan}

Now assume, as we do in Table 2, that the household applies for a HEMAP loan rather than a HAMP modification. In this case, the terms of the mortgage are unaffected. Instead, the borrower uses the loan to pay off the arrearages, making him or her current on the mortgage, while a payment of $\$ 452$ per month is made by HEMAP to the lender. This reduces the DTI (after-tax) ratio on the mortgage to 0.40 - a reduction equivalent to that achieved under HAMP. Assume also that nine months after participating

\footnotetext{
${ }^{19}$ We set the unemployment insurance benefit at 40 percent of the worker's former monthly earnings.

${ }^{20}$ The median reduction in monthly payments for a permanent HAMP modification is \$522 (see http://www.treasury.gov/initiatives/financial-stability/results/ MHA-Reports/Documents/Dec\%202010\%20MHA\%20Report\%20Final.pdf).

${ }^{21}$ This figure includes $\$ 5,000$ credited to the borrower toward his or her mortgage. We assume that the government's cost of funds is 3 percent, which we use to discount the HAMP subsidies when calculating the discounted cost.
}

in the program, the unemployed borrower finds a job. ${ }^{22}$ The loan payments stop and the household begins to pay off the HEMAP loan. The total loan balance is $\$ 14,856$, comprising $\$ 10,792$ that was used to pay off the arrearages on the mortgage and $\$ 4,068$ in accumulated monthly payments.

To determine the monthly repayment amount for a HEMAP loan, the program calculates the borrower's "total housing expense," which is the sum of the monthly principal, interest, mortgage taxes, house insurance, and utilities. Currently, if 35 percent of the household's reemployment earnings exceeds its total housing expense by at least $\$ 25$, then the household's monthly payment is the difference between the two. In this case, interest on the HEMAP loan begins to apply, with the current interest rate set at 5.25 percent. If the difference between the two is less than $\$ 25$, then the household makes a minimum monthly repayment of $\$ 25$ and no interest is charged to the loan.

Assume that the primary earner is reemployed at an income that is 90 percent of his or her prior income. Here, 35 percent of the household's monthly income is $\$ 1,500$. If monthly utilities are $\$ 100$, then the household's total housing expense is $\$ 1,482$. The household would then make the minimum monthly repayment amount of $\$ 25$. The effective DTI ratio for the household during this repayment period is 0.33 .

A borrower making the minimum monthly payment, even at zero interest, would require forty-five years to completely pay off the loan. The duration of the repayment period, then, is determined by the amount of time needed for the borrower's home equity to reach a sufficient level for the household to refinance and pay off the remaining HEMAP balance. Assuming conservatively no house price appreciation and refinancing by the borrower into a Federal Housing Authority loan with a minimum down-payment, the loan could be prepaid in about forty months. With some house price appreciation, this duration would be shorter. Taking into account all of the cash flows - including payments made to make the homeowner current, HEMAP's monthly contributions, the \$25 minimum payments made by the homeowner, and the remaining balance based on a forty-month repayment period - the discounted cost to Pennsylvania of the HEMAP loan is around $\$ 1,600{ }^{23}$

\footnotetext{
22 We assume that participants receive unemployment insurance benefits for the entire nine months of their unemployment spell, implying a thirteen-week extension of the regular twenty-six-week benefit period. In the current downturn, the federal government extended the basic state benefit period well beyond thirtynine weeks. Between 1983 and 1985, eligible unemployed workers in Pennsylvania could receive benefits for up to forty-two weeks and, as a result of a federal supplemental program, could extend this period for up to fifty-five weeks in 1983 (information supplied to the authors by the Pennsylvania Department of Labor and Industry).

${ }^{23}$ Here again, we assume that the state's cost of funds is 3 percent, which we use to discount the HEMAP cash flows.
} 


\section{Issues Associated with a HAMP-HEMAP Comparison}

The biggest difference to emerge from our comparison of the two approaches to providing assistance is the cost to the government. The HAMP approach of using cash payments to encourage lenders/servicers to modify the loan yielded a discounted cost of about $\$ 13,600$ over the five-year modification period. If the household redefaults during the period, then the discounted cost would be lower. In contrast, the HEMAP approach of providing a loan yielded a discounted cost of $\$ 1,600$. The HEMAP loan is also tailored to the length of unemployment, whereas the period of the HAMP modification is fixed in advance, regardless of how long unemployment lasts. The lender/servicer incurs little or no cost under HEMAP, since the loan keeps the borrower current; under HAMP, the lender experiences losses associated with the lower interest rate on the modified loan and, possibly, with the lower principal payments for the modification period. Finally, unlike a HEMAP loan, a HAMP modification provides the household with a below-market interest rate for a five-year period. This amounts to giving the household an annual interest rate subsidy of nearly $\$ 6,700$ as long as the household does not move. This in-place financial subsidy could reduce the household's mobility. ${ }^{24}$ In contrast, the HEMAP loan does not have the same in-place financial incentives and thus imposes fewer constraints on household mobility, because the homeowner can repay the loan even if he or she leaves the state.

HAMP's relatively short period of operation complicates our comparison of HEMAP loan outcomes with those of HAMP loan modifications. ${ }^{25}$ In addition, the percentage of HAMP modifications made to negative equity borrowers was much higher than the comparable percentage for HEMAP loans. Recall that to date, the repayment rate for HEMAP loans is around 80 percent. Ultimately, the success of HAMP can be measured by the percentage of families that avoid foreclosure. An intermediate success measure is the percentage of HAMP permanent modifications that do not redefault over the five-year period in which the modification is in effect. Each of these two success measures will require many years of data to evaluate fully.

\section{Designing a Program of Financial Assistance}

for Unemployed Homeowners

A key focus of current national housing policy is keeping homeowners in their residences in the face of a job loss or other financial hardship. While mortgage modifications have gained support as the conventional policy to aid homeowners, our examination of

\footnotetext{
${ }^{24}$ Ferreira, Gyourko, and Tracy (2010) find that each $\$ 1,000$ of in-place financial subsidies reduces a household's two-year mobility rate by 12 percent. The HAMP subsidy in our example would generate an estimated 80 percent reduction in a household's two-year mobility rate over the five-year period in which the permanent modification is in effect.

${ }^{25}$ The first cohort of permanent HAMP modifications was made in November 2009.
}

Pennsylvania's HEMAP suggests that loans that tide borrowers through a temporary period of financial hardship are a potentially attractive alternative approach to preventing foreclosures, particularly for unemployed borrowers with a good payment history and sound prospects for resuming their mortgage payments.

Policymakers considering the design of efforts to assist borrowers suffering financial hardship can look to the HEMAP experience to offer guidance in several areas. With regard to the target population, programs of financial assistance are likely to be more efficient if focused on those experiencing financial hardship due to unemployment. A minority of HEMAP participants experienced hardship unrelated to a job loss, while almost half of participants who ultimately failed to repay their loan cited factors other than unemployment as their reason for default. Hardship resulting from factors such as serious illness or divorce may be better handled in programs tailored to those specific needs.

A program targeted to the unemployed could also allow the assistance to be better timed. Many workers apply for unemployment insurance benefits within a week or two of losing their job; the unemployment insurance application could simultaneously trigger an application for mortgage assistance. With a more timely determination of loan eligibility, lenders/servicers would see fewer delinquencies and the loan amount would likely be lower because there would be less need for funds to cover arrearages. In addition, borrowers eligible for financial assistance would not have to exhaust their savings or take on other forms of debt in attempting to remain current.

A feature of distressed housing markets outside of Pennsylvania is the sizable fraction of borrowers who are in negative equity. This has not been an important part of the historical experience with HEMAP. Home price growth in Pennsylvania in the early 1980s was weak, but the state did not see the kind of sharp declines that have occurred in the past several years in states such as California, Arizona, or Florida. Unemployed borrowers in negative equity present a challenge to programs like HEMAP. In these cases, a "HEMAP-like" loan would essentially be unsecured; as such, the loan would carry substantially greater risk.

To address this issue, HEMAP administrators could stipulate that, as a condition of the loan, the lender/servicer reduce the principal on the mortgage to bring the mortgage balance down to the current value of the house. When a negative equity borrower is employed, the lender/servicer may be reluctant to write down principal on the premise that the borrower is likely to continue to make the monthly mortgage payments. However, the incentive for the lender/servicer to write down principal increases significantly once a negative equity borrower experiences a job loss. Moreover, the potential to qualify the borrower for a HEMAP loan, which insures the borrower's ability to make the mortgage payments for at least two years, is additional incentive for the lender/servicer 
to agree to write down the mortgage balance. Writing down the balance on the mortgage will also reduce the size of the HEMAP loan, since the borrower's monthly payments will be reduced. ${ }^{26}$

Once a loan is made, the timely repayment of principal and interest becomes an issue. Under HEMAP, default rates on loans have been on the order of 20 percent. Nevertheless, the potential for defaults suggests that limits on a borrower's total monthly recurring debt-to-income ratio, or back-end DTI, might be introduced. Neither HEMAP nor HAMP places explicit caps on backend DTIs when determining eligibility. ${ }^{27}$ Future loan programs might want to consider imposing a maximum back-end ratio on borrowers in order to achieve a certain comfort level regarding the borrower's ability to repay the loan.

HUD's Emergency Homeowners' Loan Program has been in operation for only a short time, so program data are not yet available. Still, EHLP bears many similarities to HEMAP in that it provides short-term assistance to eligible delinquent borrowers to pay off arrearages and bridge monthly payment shortfalls following a significant loss of income. There are key differences, however-namely, EHLP does not charge interest on the loan and it allows a borrower to earn credits to offset the total loan balance if he or she stays current on the first mortgage for five years. Thus, the program is likely to have a much higher discounted cost per loan than HEMAP would. Moreover, EHLP's financial incentives to keep a borrower in his or her home would likely constrain mobility to a much greater extent than HEMAP would. Lending under both programs, though, would be subject to higher risk in

\footnotetext{
26 This action requires that the value of the property be ascertained prior to HEMAP loan approval. This could be accomplished using automated valuation methods rather than more expensive appraisals.

${ }^{27}$ HAMP does require borrowers to receive credit counseling when the ratio is 0.55 or higher.
}

cases where the borrower is in negative equity and would likely be contingent upon some form of principal reduction.

\section{Conclusion}

Interventions to reduce foreclosures are most effective when they address the source of the problem. Approaches that modify the mortgage are sound if the borrower-even when employedhas difficulty affording the mortgage. If the borrower can afford the mortgage but has suffered a temporary reduction in income because of unemployment, then the provision of financing to the borrower during the spell of unemployment may be preferable to mortgage modification as a form of assistance. Lending to unemployed borrowers, however, is generally risky and unlikely to be undertaken on a large scale by private sector lenders. Nevertheless, Pennsylvania's experience with the Homeowners' Emergency Mortgage Assistance Program suggests that lending by the government to a carefully screened group of unemployed borrowers can be a successful strategy to reduce foreclosures. The target population can be readily identified through unemployment insurance claims filed at the time of layoff, and the program can be timed to kick in before the borrower becomes seriously delinquent or in foreclosure. The duration of the lending can be flexible and adapted to the individual experiences of unemployed borrowers.

The authors thank Brian Hudson and staff at the Pennsylvania Housing Finance Agency for providing data and answering questions on HEMAP. For data on extended unemployment benefits in the early 1980s, the authors thank Danielle Bowser and staff at the Pennsylvania Department of Labor and Industry.

\section{References}

Ferreira, Fernando, Joseph Gyourko, and Joseph Tracy. 2010. "Housing Busts and Household Mobility." Journal of Urban Economics 68, no. 1 (July): 34-45.

\section{ABOUT THE AUTHORS}

James Orr is an assistant vice president and John Sporn an assistant economist in the Research and Statistics Group of the Federal Reserve Bank of New York; Joseph Tracy is an executive vice president and senior advisor to the Bank's President; Junfeng Huang is a senior bank examiner in the Financial Institutions Supervision Group.

Current Issues in Economics and Finance is published by the Research and Statistics Group of the Federal Reserve Bank of New York. Linda Goldberg and Erica L. Groshen are the editors.

Editorial Staff: Valerie LaPorte, Mike De Mott, Michelle Bailer, Karen Carter

Production: Carol Perlmutter, David Rosenberg, Jane Urry

Subscriptions to Current Issues are free. Send an e-mail to Research.Publications@ny.frb.org or write to the Publications Function, Federal Reserve Bank of New York, 33 Liberty Street, New York, N.Y. 10045-0001. Back issues of Current Issues are available at http://www.newyorkfed.org/research/current_issues/.

The views expressed in this article are those of the authors and do not necessarily reflect the position of the Federal Reserve Bank of New York or the Federal Reserve System. 


\section{Companion Podcast Available}

An interview with the authors of "Help for Unemployed Borrowers: Lessons from the Pennsylvania Homeowners' Emergency Mortgage Assistance Program" is available on the Bank's website, at http://www.newyorkfed.org/multimedia/audio.html. In the interview, the authors provide additional insights into the advantages of the state program and its applicability to mortgage relief efforts at the federal level.

\section{MORE ON PUBLIC POLICY APPROACHES TO MORTGAGE RELIEF}

\section{Second Chances: Subprime Mortgage Modification and Re-Default}

Andrew Haughwout, Ebiere Okah, and Joseph Tracy Federal Reserve Bank of New York Staff Reports, no. 417, December 2009

Mortgage modifications have become an important component of public interventions designed to reduce foreclosures. In this paper, the authors examine how the structure of a mortgage modification affects the likelihood of the modified mortgage re-defaulting over the next year. Using data on subprime modifications that precede the government's Home Affordable Modification Program, they focus on those modifications in which the borrower was seriously delinquent and the monthly payment was reduced as part of the modification. The average re-default rate over the twelve months following the modification is 56 percent. The data indicate that the re-default rate declines with the magnitude of the reduction in the monthly payment, but also that the redefault rate declines relatively more when the payment reduction is achieved through principal forgiveness as opposed to lower interest rates.
The Homeownership Gap

Andrew Haughwout, Richard Peach, and Joseph Tracy

Federal Reserve Bank of New York Current Issues in Economics and Finance 16, no. 5, May 2010

Recent years have seen a sharp rise in the number of negative equity homeowners - those who owe more on their mortgages than their houses are worth. These homeowners are included in the official homeownership rate computed by the Census Bureau, but the savings they must amass to retain their home or purchase a new home are daunting. Recognizing that these homeowners are likely to convert to renters over time, the authors of this analysis calculate an "effective" rate of homeownership that excludes negative equity households. They argue that the effective rate -5.6 percentage points below the official rate-may be a useful guide to the future path of the official rate.

\section{MONITORING TROUBLED MORTGAGES: THE NEW YORK FED'S CREDIT CONDITIONS WEBSITE}

The Federal Reserve Bank of New York's U.S. Credit Conditions website (http://www.newyorkfed.org/creditconditions) offers detailed, timely data on the incidence of mortgage foreclosures and delinquencies in the nation and in individual states and counties. The information, presented through charts, interactive maps, and spreadsheets, is designed to help government agencies, community groups, commercial institutions, and other practitioners better understand and respond to local conditions associated with failed and troubled mortgages.

The website offers many informative features. Visitors can compare delinquency rates across geographical areas and across types of mortgages - for example, prime, subprime, or Fannie Mae and Freddie Mac. Similar information is available for credit card debt and for student and automobile loans. In addition, visitors can view charts tracking mortgage debt as a share of household liabilities or the quarterly changes in new foreclosures by state. The Credit Conditions website draws extensively on the FRBNY Consumer Credit Panel, a new longitudinal database containing credit report information for a group of individuals and households from 1999 to 2011. 


\section{BACK ISSUES}

Recent editions of Current Issues are available at http://www.newyorkfed.org/research/current_issues/.

\begin{tabular}{|c|c|c|}
\hline 2011 & Title & Author(s) \\
\hline January & Income Effects of Federal Reserve Liquidity Facilities & Fleming, Klagge \\
\hline \multicolumn{3}{|l|}{2010} \\
\hline December & Why Is the Market Share of Adjustable-Rate Mortgages So Low? & Moench, Vickery, Aragon \\
\hline August/September & $\begin{array}{l}\text { Improving Survey Measures of Household } \\
\text { Inflation Expectations }\end{array}$ & $\begin{array}{l}\text { Bruine de Bruin, Potter, Rich, Topa } \\
\text { van der Klaauw }\end{array}$ \\
\hline June/July & $\begin{array}{l}\text { The Recession's Impact on the State Budgets of New York } \\
\text { and New Jersey }\end{array}$ & Deitz, Haughwout, Steindel \\
\hline May & The Homeownership Gap & Haughwout, Peach, Tracy \\
\hline April & The Federal Reserve's Foreign Exchange Swap Lines & Fleming, Klagge \\
\hline March & $\begin{array}{l}\text { Bypassing the Bust: The Stability of Upstate New York's Housing } \\
\text { Markets during the Recession }\end{array}$ & Abel, Deitz \\
\hline February & The Unemployment Gender Gap during the 2007 Recession & Şahin, Song, Hobijn \\
\hline January & Is the International Role of the Dollar Changing? & Goldberg \\
\hline 2009 & & \\
\hline
\end{tabular}

$\begin{array}{lll}\text { December } & \text { Why Are Banks Holding So Many Excess Reserves? } & \text { Keister, McAndrews } \\ \text { November } & \text { Do Alternative Measures of GDP Affect Its Interpretation? } & \text { Hobijn, Steindel } \\ \text { October } & \text { The Global Financial Crisis and Offshore Dollar Markets } & \text { Coffey, Hrung, Nguyen, Sarkar } \\ \text { September } & \begin{array}{l}\text { Is the Worst Over? Economic Indexes and the Course } \\ \text { of the Recession in New York and New Jersey }\end{array} & \text { Bram, Orr, Rich, Rosen, Song } \\ \text { August } & \text { The Federal Reserve's Primary Dealer Credit Facility } & \text { Adrian, Burke, McAndrews } \\ \text { July } & \text { Productivity Swings and Housing Prices } & \text { Kahn } \\ \text { February } & \begin{array}{l}\text { The Term Securities Lending Facility: } \\ \text { Origin, Design, and Effects }\end{array} & \text { Fleming, Hrung, Keane } \\ \text { January } & \text { What's Behind Volatile Import Prices from China? } & \text { Amiti, Davis }\end{array}$

